\title{
Motivation, Work Environment and Organizational Commitment to Performance at the Regional Local Government Bureau Regency of Provincial Area South Sulawesi
}

\author{
Rismawati ,Mulyadi Hamid \\ Universitas Fajar Makassar
}

\begin{abstract}
Methods in collecting data in this study are questionnaires, interviews, and documentation. Methods of data analysis using descriptive and quantitative method with multiple linear regression analysis is used to measure the Factors Influencing Employee Performance Against Local Government Bureau Secretariat On Sulawesi Selatan consisting of motivation, working environment and Organizational Commitment. Based on the $F$ test of independent variables (Motivation, Work Environment and Organizational Commitment) together have a positive and significant influence on the dependent variable (employee performance). Through testing the correlation coefficient $(R)$ obtained that the level of correlation or relationship between Motivation, Work environment and Organizational Commitment to Employee Performance is a high relationship that is $84.1 \%$. And organizational commitment is the most dominant factor influencing performance Bureau of Local Government Employees At the Regional Secretariat of South Sulawesi province. Organizational performance is always related to productivity. An organization is called productive when it can achieve its goals, by transferring inputs to output at the lowest cost. Performance within the organization is the answer to the success and failure of the organization goals that have been set. Leaders or managers often do not pay attention unless it is very bad or everything goes awry. Some of these are quite interesting and important issues, because they benefit the interests of individuals, communities, nations and countries. One of the factors that can lead to greater employee productivity are efforts to increase employee motivation adequate, such as meeting the needs of both internal or external. There are several other factors that may affect the performance of government apparatus in addition to motivation. Another factor that also affects the performance of employees within a company is the work environment. Although the work environment does not carry out work processes within a company, but the work environment has a direct influence on employees who carry out the work process. The Regional Government Bureau is headed by the Head of Bureau which has the main duty of preparing materials, coordination, guidance, facilities, monitoring and evaluation of compilation and implementation of local government implementation policy, local government performance, autonomous regional development and governance arrangement. According to the Governor Regulation No. 5 of 2009 on the Main Duty, Function and Details of the Duties of Structural Position at the Regional Secretariat of South Sulawesi Province, that the SubDivision of Administration of the Regional Representative Council is preparing the materials and examining administrative files in the framework of proposal, approval, dismissal and appointment of the chairman and members of the House of Representatives District / Municipal and Provincial Parliament. Absence or absenteeism is one indicator that can be used as a tool to measure employees' organizational commitment to the company. As suggested by Mathis and Jackson (2000), that: "The commitment the organization has a significance level of trust and acceptance workforce to organizational goals and have a desire to remain in the organization, which in turn is reflected in the statistics absence and went out of labor". Things like this, showing the employees have a low attitude of work discipline. Thus it can be said that the organizational commitment was low. Based on the problems described above, the writer interested to do research titled "Factors Influencing Employee Performance Against Local Government Bureau Secretariat On Sulawesi Selatan".
\end{abstract}

\section{Method}

The research was conducted at the Bureau of Local Government Regional Secretariat of South Sulawesi province. The choice of location is based on the consideration of the acquisition of data and information easily available and do not cost too much, and are relevant to the subject matter which is the object of research. Population is the sum of all objects (units / individuals) whose characteristics are to be expected (Djarwanto, 1998: 107). The population is the total number of which will be the object of research is all employees (ANS) in the Bureau of Local Government Regional Secretariat of South Sulawesi province with the number of 253 people. The study sample is part of the population taken as a data source and can represent the entire population. Seeing the large population, the sampling using Proportional Random samplin statified techniques, Total sample is 72 respondents. Data collection methods used in this study are as follows: Questionnaires are data collection through a list of questions or a questionnaire distributed to respondents, 
Observation is a technique of collecting data through direct observation of daily activities related to aviation, Documentation is data collection techniques by studying the documents, reports and information relating to research, Interview is data collection techniques to conduct interviews to obtain information from respondents relevant to the research. The method used in this research is the multiple regression analysis to test the hypothesis with SPSS 21 with the formula Regression as follows:

With: $\mathrm{Y}=$ Employee performance;

\section{$\mathbf{Y}=\mathbf{b o}+\mathbf{b}_{1} \mathbf{x}_{1}+\mathbf{b}_{2} \mathbf{x}_{2}+\mathbf{b}_{3} \mathbf{x}_{3}+\square$}

$\mathrm{x} 1$ = Motivation;

x $2=$ an Environmental Work;

$\mathrm{x}_{3}=$ Organizational Commitment;

b 0 = Constant regression;

$\mathrm{b}_{1}, \mathrm{~b}_{2, \ldots} \mathrm{b}_{3}=$ Regression coefficients (parameters) to be estimated; $\mathrm{E}=$ Error term

Furthermore, to determine the effect of independent variables on related variables, both together ( $\mathrm{F}$ test) or individually t-test and the coefficient of determination (R 2) and partially ( $\mathrm{r}^{2)}$.

Performance is the result of work achieved by employees in carrying out the tasks assigned to him. Effective performance is the minimum acceptable level of work output. This is usually the boundary line where employees who work below this line are considered incompetent to do the job. Performance of employees can be seen based on indicators Loyalty, honesty, skill, attitude and behavior and responsibility is the degree of selfbonding to the organization.

Motivation is "giving impulses that cause the individual to act in the person behaves in a way that leads to the goal". Someone who has high motivation, then he will work hard, maintain hard steps, and have selfcontrolled behavior toward important goals. Thus the high motivation of an employee in the work will result in high performance as well. Indicators used to measure the motivation of the following payments / wages, job security, relationships among workers, supervision (supervisors) and the work itself.

The work environment is all the circumstances that occur relating to the relationship work, either relationship with superiors or peer relationships, or relationships with below. Indicators Working Environment is measured by respondent's opinion as follows: Continuous and tight supervision, Working atmosphere encourages morale, rewards, harmonious relationships and Employees are treated objectively.

Organizational commitment is a belief that binds a person with the organization where he works, which is shown by loyalty, involvement in work and identification of organizational values and goals. As a grand theory that distinguishes the organizational commitment of three components: affective commitment (affective commitment), continuance commitment (continuence commitment) and normative commitment (normative commitment). Affective commitment (Affective Commitment), indicators: Trust in the organization's objectives, Continuing Commitment (Commitment Continuence): Motivation based benefits, work motivation based on contributions. Normative commitment (Commitment Normative): To uphold the duties and obligations imposed, Maintaining a positive image of the organization. And all of the above variables are measured using the Likert scale by grouping into five categories: (i) $5=$ Strongly agree, (ii) $4=$ Agree, (iii) $3=$ Less agree, (iv) 2 $=$ Disagree,$(\mathrm{v}) 1=$ Strongly disagree.

\section{Results And Discussion}

\section{Descriptive Analysis}

Descriptive analysis is the result of research that describes the analysis of several factors that influence employee performance Bureau Local Government Regional Secretariat of South Sulawesi province, based on the feasibility employee respondents respondents in providing information to the questionnaire questions submitted in accordance with the level of understanding of the substance of the respondent. The study looked at variables $\mathrm{Y}$ and $\mathrm{X}$, diimana dependent variable is employee performance (Y), while the independent variable is the motivation $(\mathrm{X} 1)$, work environment $\left(\mathrm{X}_{2}\right)$, and organizational commitment of employees $\left(\mathrm{X}_{3)}\right.$. The frequency distribution of respondents' answers result is a tendency level perception of the study variables, such as motivation, work environment, and organizational commitment to employee performance $n$ the Bureau of Local Government Secretariat Office of Sulawesi Selatan.

\section{Testing of Research Instruments}

According Sugiyono (2007: 233), corrected item total correlation is a correlation between the total score of the item, so open to interpretation by consulting the critical value of $r$-table, if $r$ arithmetic $>r$ - critical value tables product moment the instrument is valid or it can be said that the item statement From the reflection of each variable in this study its existence on the research instrument is valid (valid).

Reliability test is performed to know the stability and consistency if re-measured with the same subject. Reliability measurement is done by using Cronbach's alpha (Cronbach alpha). From the test results are analyzed 
by comparing the $\mathrm{R}$ table can be searched by interpolating the number of questions with the coefficient of reliability.

Test Validity and Reliability Test

\begin{tabular}{|c|c|c|c|c|c|}
\hline Question items & $\begin{array}{c}\text { Pearson's } \\
\text { Correlatian }\end{array}$ & $\begin{array}{c}\text { Sig / P } \\
\text { value }\end{array}$ & Information & $\begin{array}{c}\text { Cronbach } \\
\text { Alpha }\end{array}$ & Information \\
\hline $\begin{array}{l}X_{1.1} \\
X_{1.2} \\
X_{1.3} \\
X_{1.4} \\
X_{1.5}\end{array}$ & $\begin{array}{l}0710 \\
0.705 \\
0.698 \\
0.616 \\
0.674\end{array}$ & $\begin{array}{l}0.000 \\
0.000 \\
0.000 \\
0.000 \\
0.000\end{array}$ & $\begin{array}{l}\text { Valid } \\
\text { Valid } \\
\text { Valid } \\
\text { Valid } \\
\text { Valid }\end{array}$ & 0.762 & Reliable \\
\hline $\begin{array}{l}X_{2.1} \\
X_{2.2} \\
X_{2.3} \\
X_{2.4} \\
X_{2.5}\end{array}$ & $\begin{array}{l}0.641 \\
0.749 \\
0.710 \\
0.649 \\
0.706\end{array}$ & $\begin{array}{l}0.000 \\
0.000 \\
0.000 \\
0.000 \\
0.000\end{array}$ & $\begin{array}{l}\text { Valid } \\
\text { Valid } \\
\text { Valid } \\
\text { Valid } \\
\text { Valid }\end{array}$ & 0.740 & Reliable \\
\hline $\begin{array}{l}X_{3.1} \\
X_{3.2} \\
X_{3.3} \\
X_{3.4}\end{array}$ & $\begin{array}{l}0.709 \\
0.725 \\
0.710 \\
0.642 \\
0.706\end{array}$ & $\begin{array}{l}0.000 \\
0.000 \\
0.000 \\
0.000 \\
0.000\end{array}$ & $\begin{array}{l}\text { Valid } \\
\text { Valid } \\
\text { Valid } \\
\text { Valid } \\
\text { Valid }\end{array}$ & 0.738 & Reliable \\
\hline $\begin{array}{l}\mathrm{Y}_{1.1} \\
\mathrm{Y}_{1.2} \\
\mathrm{Y}_{1.3} \\
\mathrm{Y}_{1.4} \\
\mathrm{Y}_{1.5}\end{array}$ & $\begin{array}{l}0.687 \\
0.748 \\
0.726 \\
0.709 \\
0.614\end{array}$ & $\begin{array}{l}0.000 \\
0.000 \\
0.000 \\
0.000 \\
0.000\end{array}$ & $\begin{array}{l}\text { Valid } \\
\text { Valid } \\
\text { Valid } \\
\text { Valid } \\
\text { Vali d }\end{array}$ & 0742 & Reliable \\
\hline
\end{tabular}

Source: The results of data processing SPSS 212017

From the table reliability test with Cronbach Alpha method can be seen that the value of the coefficient of reliability count when compared with the result of a calculation coefficient table turns $\mathrm{R}$ arithmetic $>\mathrm{R}$ table. Because the reliability coefficient of testing is greater than the coefficient of table reliability it can be concluded that the instrument proved reliable. From the data processing on the obtained test reliability coefficient of reliability (Cronbach's Alpha) for the variable performance of 0762, the motivation variable $0.740,0.738$ work environment and organizational commitment variables 0742.

\section{Hypothesis testing}

Based on the result of classic assumption test which consist of normality test, multicollinearity test, and heterokedasticity test showed that the multiple regression estimation has fulfilled the requirements of classical assumption so that the result is expected to be good in analyzing the influence of the independent variable to the dependent variable. Testing of regression result obtained was tested simultaneously by using F-test and partial test by using t-test. Then it can be described for more details:

Hypothesis testing

\begin{tabular}{|c|c|c|c|c|c|c|c|}
\hline \multirow[t]{2}{*}{ HIP } & Variable & Variable & \multicolumn{5}{|c|}{ Direct Effect } \\
\hline & Independent & Dependent & $\mathrm{B}$ & Beta & T-hit & P-value & Ket \\
\hline $\mathrm{H} 1$ & Motivation & $\begin{array}{c}\text { Employee } \\
\text { performance }\end{array}$ & 0.195 & 0.194 & 2,627 & 0.011 & Sig. \\
\hline $\mathrm{H} 2$ & Work environment & $\begin{array}{c}\text { Employee } \\
\text { performance }\end{array}$ & 0.072 & 0077 & 1.140 & 0.258 & Tdk Sig. \\
\hline $\mathrm{H} 3$ & Organizational commitment & $\begin{array}{c}\text { Employee } \\
\text { performance }\end{array}$ & 0718 & 0.715 & 9.854 & 0.000 & Sig. \\
\hline \multicolumn{8}{|c|}{$\mathrm{R}=0.815$} \\
\hline \multicolumn{3}{|c|}{ R Square $=0.664$} & \multicolumn{5}{|c|}{ Ajust R square $=0.653$} \\
\hline \multicolumn{3}{|c|}{$F=60.669$} & \multicolumn{5}{|c|}{ Sig $=0.000$} \\
\hline
\end{tabular}

Source: Data processed in 2017

Based on the results of the ANOVA analysis, the first hypothesis of research that states that factors consist of motivation, work environment and employee organizational commitment to employee performance at the Local Government Secretariat Bureau of Sulawesi Selatan acceptable.

The result of multiple linear regression equation from this research model is as follows:

Information :

$$
Y=0094+0.195 X_{1}+0.072 \times 718 X_{2}+0.3
$$

Y. = Employee Performance

$\mathrm{X}_{1}=$ Motivation 
$\mathrm{X}_{2} \quad=$ The work environment

$\mathrm{X}_{3}$ = Organizational commitment

Judging from standardizied beta coefficient, regression equation showing the effect of each variable independent of the performance of employees.

\section{Classical Assumption Testing}

\section{Normality test}

Test Normality data is to determine whether a variable is normal or not. To know the probability of normally distributed data, the authors have conducted data testing with Kolmogorof-Smirnov test. Smirnov is by comparing the distribution of data (which will be tested normality) with the normal standard distribution.

Table Kolmogorof-Smirnov

\begin{tabular}{|c|c|c|c|c|c|}
\hline \multicolumn{6}{|c|}{ One-Sample Kolmogorov-Smirnov Test } \\
\hline & & Motivation & $\begin{array}{c}\text { Work } \\
\text { environment }\end{array}$ & Commitment org. & PERFORMANCE \\
\hline \multicolumn{2}{|l|}{$\mathrm{N}$} & 72 & 72 & 72 & 72 \\
\hline \multirow[t]{2}{*}{ Normal Parameters ${ }^{\mathrm{a}, \mathrm{b}}$} & Mean & 4.119 & 4.006 & 3.992 & 4.053 \\
\hline & STD. Deviation & .4743 & .5057 & .4752 & .4771 \\
\hline \multirow[t]{3}{*}{ Most Extreme Differences } & Absolute & .179 & .219 & .215 & .205 \\
\hline & Positive & .102 & .120 & .086 & .122 \\
\hline & Negative & -.179 & -.219 & -215 & -.205 \\
\hline \multicolumn{2}{|l|}{ Kolmogorov-Smirnov Z } & .179 & .219 & .215 & .205 \\
\hline \multicolumn{2}{|l|}{ Asymp. Sig. (2-tailed) } & $.000^{2}$ & $.000^{\mathrm{a}}$ & $.000^{\mathrm{a}}$ & $.000^{\mathrm{a}}$ \\
\hline \multicolumn{6}{|c|}{ A. Test distribution is Normal. } \\
\hline \multicolumn{6}{|l|}{ B. Calculated from data. } \\
\hline
\end{tabular}

Based on these test results obtained nil 0,000 motivation ai significance, the significant value of the work environment and the significant value 0,000 0,000 organizational commitment. Based on these results, the significance value of all three variables under study data is normally distributed. This means it is feasible to be used as an ingredient in the next stage of data processing.

\section{Multicollinearity Test}

Multicolinearity means between independent variables contained in the regression model has a perfect linear relationship or near perfect (high correlation coefficient or even 1). A good regression model should not have perfect or near perfect correlation between the independent variables. The existence of multicollinearity can be seen through the VIF (Variance Inflation Factorrs) or the value of tolerance, that is, if VIF $<10$ or opposite to see the tolerance values> 0.1 .

\section{Multicollinearity Test Results} coefficients $^{\text {a }}$

\begin{tabular}{|c|c|c|c|}
\hline \multirow[t]{2}{*}{ Model } & & \multicolumn{2}{|c|}{ Collinearity Statistics } \\
\hline & & Tolerance & VIF \\
\hline \multirow{4}{*}{1} & (Constant) & & \\
\hline & Motivation & .430 & 2.325 \\
\hline & Work environment & .516 & 1.937 \\
\hline & Organizational commitment & .444 & 2.251 \\
\hline
\end{tabular}

A. Dependent Variable: Y

From the multicolinearity test results show that all variables have VIF value $<10$ and the tolerance value $>0.1$. This indicates that there is an indication of multicolinearity in the equation and no proven or no multicolinearity in the equation or the relationship between the independent variables can be tolerated so as not to interfere with the regression result.

\section{Discussion}

The results showed the variables of education, training and deployment of staff jointly or individually significant effect on employee performance Bureau of Local Government Secretariat Office of Sulawesi. The discussion about the effect of variable motivation, work environment and employee organizational commitment to employee performance at the Local Government Secretariat Bureau of Sulawesi, each of which can be described as follows: 


\section{Effect of Motivation ( $\mathrm{X}_{1}$ ) Employee Performance Against Local Government Secretariat Bureau of Sulawesi}

The results of hypothesis testing have proved that there is influence between motivation to employee performance Bureau of Local Government Secretariat Office of Sulawesi. This means that the motivation is partially positive and significant impact on the performance of employees of the Bureau of Local Government Secretariat Office of Sulawesi. This test statistically proves that motivation to employee performance Bureau of Local Government Secretariat Office of Sulawesi a rtinya that there is a positive influence between the variables of motivation to employee performance Bureau of Local Government Secretariat Office of Sulawesi. This can be seen in the relations of good cooperation to all employees and managers will be motivated to work and with their supervision in each division will encourage employees to complete the work then increase in performance in the Office of the Bureau of Local Government Secretariat of the Province of South Sulawesi can improve the performance of employees.

This is in line with research from Meanwhile, according to Joko Purnomo (2008) in his research on leadership, work motivation, and work environment, on employee performance showed significant results. Where the variables of work and environmental motivation that have a significant effect on employee performance. This research was conducted on civil servants at the Forestry and Plantation Office of Jepara Regency. Proved to influence In this study, these factors were analyzed to determine the effect of work motivation and work environment on the performance of employees of Industry and Commerce Office of Semarang City.

Provision of motivation is one of the goals for employees who are given the motivation to work in accordance with the reference work and responsibilities given so that the company's goals can be achieved properly. Moreover, it also contained elements Unur efforts, the efforts of qualified and directed as well as consistent with the organization's objectives to be achieved. Greenberg (1999) Rival (2005) looked at motivation as a result of three types of beliefs of the individual, consists of expectations of conviction that one's efforts will affect performance.

\section{The influence of the working environment Against Employee Performance in Local Government Secretariat Bureau of Sulawesi}

$\mathrm{H}$ Tela hypothesis testing results prove there is influence between the working environment the performance of employees in the Office of the Regional Government Bureau Regional Secretariat of South Sulawesi province. This means that the working environment is partially affect the performance of employees at the Bureau of Local Government Secretariat Office of Sulawesi Selatan. This test is statistically proven that the work environment to employee performance at the Local Government Secretariat Bureau of Sulawesi Selatan. This means that their contribution is positive but not significant that the work environment to employee performance at the Local Government Secretariat Bureau of Sulawesi Selatan.

This can be seen in the conclusion of the respondent's answer in the supervision carried out continuously by using a strict supervision system, and the second highest frequency is the employee gets fair and objective treatment. Supposedly with the answers of respondents above will help improve the performance of employees at the Regional Government Bureau Office Regional Secretariat South Sulawesi Province but in fact it is inversely proportional to the facts and facts on the ground, even if employees in completing the work with a routine supervision system makes employees are not free Creative in completing their work, they tend to be more depressed with the existing work environment situation, so that there will be decreased performance of its employees. With strict supervision and objective assessment system even actually make the employees unable to complete the work, due to pressure from the leadership to immediately complete the task and work. Uncomfortable work environment will make employees actually experience a decrease in performance, so the effect of work environment on employee performance has an insignificant effect. These results support previous research by Nela Pela Rahmawati, 2014, with the title "Environmental Effects of employment of the employee performance (Study on Employee Tax Office Primary North Malang)". The results of this study indicate that based on descriptive analysis shows that the majority of respondents agree on the physical work environment and non-physical work environment that exist in the company is good so that employee performance increases. The results of multiple linear regression analysis showed that the partial physical working environment has a significant influence on the performance of employees and non-physical work environment also have a significant influence on employee performance.

Work environment has a direct influence on the employees who carry out the production process. A work environment that focuses on employees can improve performance. Conversely, inadequate work environment will be able to degrade performance and ultimately lower employee work motivation. According to Alex S Nitisemito (2000: 183) defines the work environment is the work environment is everything that is around the workers who can affect him in carrying out the tasks that are embedded. According Sedarmayati (2001: 1) defines Work environment is the whole tooling tools and materials encountered, the surrounding 
environment in which a person works, methods of work, and arrangement of work both as individuals and as a group.

\section{Influence of Organizational Commitment Against Employee Performance in Local Government Secretariat Bureau of Sulawesi}

The result of hypothesis testing has proved that there is influence between the Organizational Commitment on the performance of the employees at the Regional Government Bureau Office of Regional Secretariat of South Sulawesi Province. This means that the organization's commitment partially significant effect on the performance of employees at the Office of Regional Government Bureau Sekerariat Regional South Sulawesi Province. This test statistically proves that the organization's commitment to performance at the Regional Government Bureau of Regional Secretariat of South Sulawesi Province. This means that there is a positive and significant influence between organizational commitment variable on the performance of employees at the Regional Government Bureau of Regional Secretariat of South Sulawesi Province. This can be seen from antuasiaseme respondents' answers on organizational commitment variables which states that the improvement of employee performance at the Regional Government Bureau of Regional Secretariat of South Sulawesi Province by self-motivating the employees themselves and trying to work that is superior and work with passion in order to produce Better performance.

The fact of respondents So we can conclude that trust is part of the commitment of the organization. So Employees who are committed to work if motivated by considering the contribution that will be given to him and trust to the goals of the organization are part of an employee's commitment in improving the performance of employees at the Bureau of Local Government Secretariat Office of Sulawesi Selatan.

This is in line with the research of Setiadi (2007) conducted a research entitled "Analysis of Work Motivation Influence, Employee Commitment and Work Environment on Employee Performance (Case Study of Lippo Bank Branch of Youth, Semarang)". This study aims to analyze the influence of work environment positively and significantly to the performance of employees of Lippo Bank Pemuda, Semarang also analyze the influence of work motivation, employee commitment and work environment collectively to the performance of employees of Lippo Bank Pemuda, Semarang. The results showed that the work environment variables have a positive and significant effect on the performance. The variables of work motivation, employee commitment and work environment influence together on performance.

Organizational Commitment is a must-have attitude for every employee. Commitment is a binder that gives impetus to provide what is best terahadap what they are responsible.

Allen and Meyer (in Luthans, over the language of VA Yuwono, et al, (2006: 249) argue that each component has a different basis Employees with high affective components still join the organization because of the desire to remain an organization member Employees recognize the organization and Are bound to remain members of the organization to achieve organizational goals, while employees with high-continuity components, still join the organization because they need an organization.They stay because they will get pensions, facilities and seniority or they have to pay the transfer fee. Employees who have a high normative component remain a member of the organization because they have to do.

\section{Conclusion}

\section{Conclusions And Suggestions}

Based on the results of research and discussion it can be concluded as follows:

The results of hypothesis testing has proven there is influence of motivation on employee performance at the Local Government Secretariat Bureau of Sulawesi Selatan. Through calculations that have been done obtained ti incidence of significance is less than the value of $\alpha$ then so Ha accepted and Ho ditol a k. Through calculations that have been done obtained influence of the working environment the performance of employees in the Office of the Regional Government Bureau Regional Secretariat of South Sulawesi province with a significance level greater than $\alpha$ which means that this hypothesis me refused to accept me Ha and Ho. Through calculations that have been done shows the influence of between organizational commitment ki nerja against employees at the Bureau of Local Government Secretariat Office of Sulawesi Selatan the level of significance is less than the value of $\alpha$ which means that the hypothesis in this study me and me refuse to accept Ha Ho.

The contribution of motivation, ngan lingku work and organizational commitment the performance of employees at the Bureau of Local Government Secretariat Office of Sulawesi Selatan expressed as a percentage of 84.1 percent value variable variation Bureau Employee Performance in Local Government Secretariat South Sulawesi Province can be explained by Motivation $(\mathrm{X} 1)$, work environment $\left(\mathrm{X}_{2}\right)$ and organizational commitment (X3), so it may be said of variables are taken in the study to provide an overview of the factors affecting the performance of employees at the Office of the Regional Government Bureau Regional Secretariat of South Sulawesi province. 


\section{Suggestion}

Based on the conclusion that has been done then the suggestions that can be given in this research are:

The need for the Office of the Regional Government Bureau Secretariat South Sulawesi Province more and improved indicators that can affect motivation, work environment and commitment to improving the performance of employees' organizations so that employees can complete tasks assigned to them quickly and complete tasks with the quality and the quantity exceeds the standards set. Test results in this study indicate there are other variables that must be considered in this study. Further studies, should add other variables that can affect the performance of employees, due to the better performance of employees it will affect both also for the organization.

\section{Bibliography}

[1]. Admodiwiri, 2002. Human Resource Management, Ghalia Indonesia, Jakarta.

[2]. Arikunto. 1998. Education Management, Rhieneka Cipta, Jakarta

[3]. Armstrong, Michael and Murlis Helen. 1995. Salary administration, 3nd. Rochmulyati,

[4]. H. (translator). Administration of salary. LPPM and PT Pustaka Binaman pressindo. Jakart

[5]. Arikunto, Suharsimi. 2000. Research Procedures A Practice Approach. Yogyakarta: Rineka Cipta

[6]. Bernardian, John H and Joyce E.A Russell, 1995. McGraw-Hill Book Company, Inc.,New York. Human resources management: an experiential approach;

[7]. Casmiwaty, D. 2004. Pns compensation system in Indonesia, Sulistiyani (ed.) Understanding good governance in human resource perspective, Gava Media, Yogyakarta. 231-232

[8]. Daryanto H, 1999. Human Resources Investment, Depnaker of the Republic of Indonesia Jakarta.

[9]. Fuad Mas'ud. 2004. Organizational Diagnostic Survey: Concepts \& Applications, Publisher Agency of Diponegoro University, Semarang

[10]. Gibson Ivancevich, 1995. Organization, Behavior, Structure and Micro Process, Erlangga Publishers, Jakarta

[11]. Gibson, Ivancevich \& Donelly. 2000. Organizations, Behavior, Structure, Processes, Tenth Edition. McGraw-Hill Companies: Singapore.

[12]. Ghozali. 2005. Application of Multivariate Analysis With SPSS Program. Semarang: Diponegoro University Publishing Agency.

[13]. Gunawan Ari, 1996. School Administration, School Administration, Micro Education Administration, Rineka Cipta Jakarta.

[14]. Hasibuan, H. Malayu S.P, 2002. Human Resource Management, Second Revised Edition, Publisher BPFE-UGM, YogyakartaHasibuan. 2005.

[15]. Hellriegel \& Slocum. 2004. Organizational Behavior, Tenth Editions. Thomson: South Western.

[16]. Handoko, T. Hani. 2001. Personnel and Human Resource Management Second Edition. Yogyakarta: BPFE

[17]. Hasibuan, Malayu. 2007. Human Resource Management, Jakarta: PT. Earth Script Ichsan, Achmad Fahruddin. 2009. The Influence of Compensation on Employee Performance (Study of employees of PT Pos Indonesia (Persero) Malang

[18]. Ivancevich \& Matteson. 2002. Organizational Behavior and Management, Sixth Edition. The McGraw-Hill Companies: Singapore.

[19]. Kadarisman M. 2012. Compensation Management. Jakarta: Rajawali Pers

[20]. Kuntjoro, Zainuddin, S. 2002. Organizational Commitment. Www. E-psikologi.com/masalah.htm. Accessed February 17, 2012.

[21]. Luthans, Fred. 1985. Organizational Behavioral, Fifth Edition.

[22]. McGraw Hill International: California. 2006. Organizational Behavior Translation V.A

[23]. Yuwono, et al. English Edition. Andi: Yogyakarta.

[24]. Marni Mardjoen.2013.Pengaruh Performance Allocation Performance (TKD) on Employee Performance at Gorontalo Provincial Health Office.

[25]. Mahmudi. 2007. Public sector performance management. UPP STIM YKPN. Yogyakarta.

[26]. Mathis Robert L \& Jackon H. 2002. Human Resource Management. Jakarta: Salemba Four

[27]. Mangkunegara AP. 2005. Human Resource Management. Bandung: Rosdakarya

[28]. Manulang, M, 2002, Personnel Management, Balai Pustaka, Jakarta.

[29]. Michael Armstrong. 2009, Handbook Of Human Resourse Management Practice 11th edition. United kingdom kopar rage.

[30]. Onong uchjana Effendy. 2006. Communication Science; Theory and Practice. Bandung: Youth Publishers Rosda Karya.

[31]. Okky Setiawan (2009) with the title of research "The Influence of Training, Compensation and Work Motivation Against Work Performance Employees of Marketing Industry Division in Perum Perhutani Unit I Central Java. Government Regulation No. 58/2005 on Regional Financial Management. Regulation of the Minister of Home Affairs Number 59 of 2007 on Amendment of PERMENDAGRI Number 13 Year 2006 concerning Guidelines on Regional Financial Management.

[32]. Regulation of the Governor. 2013. Gorontalo Governor Regulation No. 03 of 2013 on Regional Performance Allowance (TKD) of Fiscal Year.

[33]. Rezsa Primanda. 2008. The Influence of Organizational Culture, Locus of Control and Application of Information System to the Performance of Public Service Apparatuses. Muhammadiyah Surakarta university. 
[34]. Rivai, Veithzal, 2005. Human Resource Management for Companies, from Theory to Practice, PT. Raja Grafindo Persada, Jakarta.

[35]. Sastradipoera, Komaruddin. 2002. Human Resource Management: An Approach to Operational Functions Issue I. Kappa-Sigma Publisher: Bandung

[36]. Terry, P. Sutton and Peter J. Bergerson.2006. Faculty Compensation System: Impact on the Quality of Higher Education.

[37]. Windy Aprilia Murty (2012) entitled 'Influence of Compensation, Motivation and Organizational Commitment to Employee Accounting Section (Case study at manufacturing company in Surabaya).

[38]. Yong Sun Paik, K Pravenn Parboteah, and Wonshul Shim. 2007. Relationship between Perceived Compensation, Employee Commitment, and Job Satisfaction: The Case of Mexican Workers and Korean Maquladores.

[39]. Yuniarsih and Suwatno, 2008. Human Resource Management. Bandung. Alfabeta 